\title{
FORTE: UM FÓRUM PELA FORMAÇÃO
}

\author{
Letícia Burck*
}

SÍNTESE - As considerações do presente artigo referem-se a demandas de paradigmas atuais associados com a pós-modemidade. Salientam-se as possiveis relações entre a fragilização do Estado de Bem Estar Social e a emergência de entidades que ocupam, cada vez mais, espaços de formação com substancial apoio da sociedade civil, apontando o Fórum de Educação para o Trabalho - FORTE, como um exemplo dessa prática, em Porto Alegre, desde 1994.

PALAVRAS-CHAVE - formação, sociedade civil, cidadania.

\begin{abstract}
The subjects of the present article refer to the current paradigms requests associated with pos-modemity happenings. It emphasize the relation between the social wellbein's fragility and the ONGs emergence these institutions take space, in a growing way, with substancial support of civil society the FORTE (Education for Labor's Forum) is one exemple of this practice performed in Porto Alegre since 1994.

KEY WORDS - formation, civil society, citizenship.
\end{abstract}

\section{1 - Introdução}

Este artigo refere-se ao projeto de pesquisa em elaboração, "Sociedade Civil \& Formação: a emergência das onGs na construção de novos paradigmas", que visa investigar como entidades de composições variadas vêm garantindo processos de formação junto ao FORTE (Fórum de Educação para o Trabalho), que desde 1994, preocupado com a profissionalização juvenil, congrega associações, escolas católicas, espíritas e luteranas, além de instituições privadas.

O mencionado Fórum é composto por mais de quarenta entidades, situadas em diferentes regiões da cidade, ${ }^{1}$ que se denominam Organizações Não Governamentais (ONGS). Reúnem-se mensalmente a analisar e propor novas práticas pedagógicas, voltadas à educação juvenil para a profissionalização.

\footnotetext{
Assistente social, Mestranda em Serviço Social da PUCRS.

Como exemplo, citamos aqui algumas entidades que congregam o FORTE: Movimento pelos Direitos da Criança e do Adolescente, Fraternidade Cristã Espirita, Centro Educacional para Deficientes Auditivos, Centro de Promoção da Criança e do Adolescente São Francisco de Assis, Clube de Mães Margarida Alves, Associação Casa Menina de Rua, Grife Morro da Cruz, Instituto São Benedito, Sociedade Pobres Servos da Divina Providência, Associação Cristã de Moços de Porto Alegre, Movimento Nacional de Meninos e Meninas de Rua, etc.
} 
O FORTE institucionaliza-se num contexto em que a sociedade civil cada vez mais ocupa os espaços antes preenchidos pelo Estado. Isso porque, nas últimas décadas, observa-se uma transformação na noção de sociedade civil. Além de representar uma terceira dimensão da vida pública, esta passa a significar "[...] um campo onde prevalecem os valores da solidariedade [...]."2

Nessa esfera social pública, ainda emergente, encontram-se os movimentos e instituições que, embora privados, têm objetivos sociais, como é o caso das onGs. ${ }^{3}$

É nessa perspectiva que podemos acompanhar o desenvolvimento de estratégias desencadeadas pelas onGs, o que ocorre de diversas maneiras. Além de interessantes para o Estado e também para o mercado, ao assumirem "novos" papéis, as referidas organizações representam "possibilidades" de investimentos sociais, que estão por serem descobertas pelas empresas.

As ONGS são privadas e prestam atendimento público. ${ }^{4}$ Promovem a articulação entre esfera pública e âmbito privado como nova forma de representação, buscando alternativas de desenvolvimento democrático para a sociedade. O reconhecimento de instituições intermediárias entre o indivíduo, mercado e Estado denotam a relevância de ações prestadas, na medida em que estão articulando diversos interesses.

Essas organizações cumprem o papel de institucionalizar principios éticos que não podem ser produzidos nem pela ação estratégica do mercado, nem pelo exercício do poder de Estado.

Segundo Claus Offe, ${ }^{5}$ "As ONGS [...] atuam como válvula de escape das deficiências do Estado e do mercado [...]" e "o Estado, a liberdade de mercado e as ONGS vão formar a nova ordem social".

É nesse sentido que a pesquisa ora em desenvolvimento busca investigar, apoiada num sistema de hipóteses, como as oNGs vêm garantindo processos de formação junto ao FORTE.

\section{2 - O FORTE: um espaço emergente de formação à cidadania}

As inúmeras habilidades atualmente exigidas pelo mercado e pela sociedade em geral precisam ser gradativamente conquistadas e integradas ao cotidiano de todo cidadão trabalhador. Nesse processo, o FORTE tem contribuido ao apontar temas e práticas que estão em vigor no mundo atual, em intensa transformação. Isso acontece mais sistematicamente através das discussões plenárias do Fórum, que repercutem nas ações e iniciativas instauradas nos processos de formação orientados pelas entidades associadas e, em conseqüência, na dinâmica das comunidades que estão inseridas.

Tais entidades, que congregam o FORTE, identificam-se enquanto ONGS, integrando os setores voltados à profissionalização juvenil e estão situadas nos segmentos sociais economicamente desfavorecidos. Essas organizações, em reuniões

2 VIEIRA, Liszt. Cidadania e globalização. Rio de Janeiro. Record, 1997. p. 63.

3 Vieira, op. cit., p. 65.

4 FERNANDES, Rubem César. Privado porém público: o terceiro setor na América Latina. 2. ed. Rio de Janeiro: Relume-Dumará, 1994, p. 65.

5 OFFE, Claus. “O novo poder”. Veja, São Paulo, ano 31, n. 14, p. 11-13, 1998. 
mensais, procuram articular e propor políticas sociais na área da infância e juventude do município de Porto Alegre, prioritariamente. Assim, o Fórum representa um exemplo concreto da emergência das onGs, que passam a se interessar por programas que atendem a demandas antes supridas pelo Estado.

Dentre as diferentes alternativas de atuação das entidades do FORTE, para "tentar" atender as referidas demandas, ressaltamos o trabalho voluntário como um aporte aos programas e projetos institucionais desenvolvidos para profissionalizar jovens em situação de risco social. Desse modo, a sociedade civil se engaja buscando agir de maneira coletiva e fortalecendo seu papel de forma participativa. Isso é vital ao processo de continuidade do Fórum, já que a sociedade civil é sua estrutura, seja organizada em entidades ou com profissionais voluntários. Nesta busca de construção da cidadania, os voluntários formam e são formados, pois as experiências praticadas se dão em diversas instâncias de atuação como dirigentes, educadores, etc., administrando gerencial e/ou operacionalmente as entidades. Assim, dada a conjuntura atual e através da frente formação, as entidades buscam cada vez mais o engajamento da sociedade civil, já que o momento favorece tais acontecimentos.

É de assinalar-se que o trabalho voluntário, atualmente regulamentado pela Lei no 9.608/98, segue representando um recurso muito importante nessas instituições. A profissionalização do trabalho social é um dos fatores fundamentais a seu decorrente sucesso e continuidade, ou seja, o compromisso voluntário e dos profissionais efetivos pode caminhar junto.

Seja através do voluntariado, das ações que as entidades vêm desencadeando junto à sociedade civil, empresas ou Estado, inúmeros agentes financiadores começam a descobrir e se interessar por novas formas de parcerias com entidades sociais "havia prêmio para artistas, jogadores e até empresários, mas não para entidades filantrópicas". ${ }^{6}$

Tendo em vista as considerações acima expostas, pode-se dizer que a sociedade civil organizada realmente vem-se constituindo em espaço de formação para cidadania, pois busca a articulação do binômio direitos e deveres de maneira participativa, supondo organização coletiva.

\section{3 - Considerações finais}

As demandas atuais de formação e competência vêm sendo propagadas pelas práticas de oNGS ativas e preocupadas com a sociedade. As instituições, ao reverem posturas e teorias, buscam espaços na competitiva ação social, atendendo diversas áreas da sociedade. É o engajamento do terceiro setor no desenvolvimento social.

\footnotetext{
“[...] A nossa sociedade está apoiada em três setores: o mercado, o setor governamental e o setor civil, também chamado de 'terceiro setor', composto por fundações e organizações não governamentais que trabalham em projetos nas áreas cultural, social e ambiental, no atendimento às comunidades e grupos sociais mais carentes e na defesa dos direitos básicos dos homens e dos povos [...]" (Grajew, 1997, p. 16). ${ }^{7}$
}

6 KANITZ, Stephen. “Caridade nota 10”. Época, Rio de Janeiro, ano 1, n. 1, p. 124-126, 1998.

7 GRAJEW, Oded. "Educação para a cidadania”. Folha de São Paulo, São Paulo, 16 jan. 1997. p. 16. 
Frente à globalização das economias torna-se emergente a globalização da cidadania, mediante direitos e deveres, acesso à informação e cumprimento das necessidades básicas. Assim, pode-se estar buscando o caminho para uma cidadania planetária. ${ }^{8}$

Finalmente, pensamos que, dada a atual conjuntura econômica e social, sendo uma das representações a emergência das onGs e as novas perspectivas de ação em segmentos da sociedade civil, bem como a necessidade da formação inserida na educação pelo trabalho, frente às demandas globais, o FORTE se constitui imerso na problemática ora pautada e ativo na reconstrução de espaços e papéis buscando a garantia da educação pelo trabalho e cidadania na profissionalização juvenil da cidade de Porto Alegre, prioritariamente.

8 Fernandes, op. cit., p. 15. 